\title{
FORESTRY ABROAD
}

\author{
By Joseph W. Michaud, B.A. Sec., \\ Forest Service of the Province of Quebec
}

$\prod$

10 MOST foresters and those actually interested in forest conservation work in our country, these two words open a vista on a world full of riches and possibilities accessible only to a few privileged ones.

The absence of leisure for some and a lack of means for the others to undertake a world's cruise have left the only resource available in such occurrence: to travel in mind to these remote lands with the aid of "Baedeker's."

In our case these guide-books are the numerous annual reports and publications issued by the various countries throughout the world.

The sylviculturist will find in them a wide scope for study in the systems used ir countries totally different in climatic conditions, species grown, etc., such as Scandinavia, Algeria, India and Australia.

Those engaged in lumbering and forest products utilization will wonder at the most diversified methods used in forest exploitation such as reindeer teams in the forest areas just nortl of the Polar Circle in Norway, cableways and overhead trolleys in Yugoslavia, trained elephants in India and Siam and ox teams in the jungles of Africa.

The technologist will be astonished at the prodigious array of timber varieties ranging in color from the creamy white of the boxwood to the violet of the purpleheart and the deepest black of Gaboon ebony, and in hardness and weight from the extremely hard and ponderous lignum vitae (guayacum) averaging 80 lbs to the cubic foot to the lightest wood known Balsa (ochroma lagopus) averaging $7 \mathrm{lbs}$ to the cubic foot. He will find most amazing structures in species such as the Lacewood of Australia, the Zebrawood of Africa, the Maidhu of Indo-China, the Thuya of Morocco and the Letterwood of South America.

Those having a Ripley's mind will gather such unknown facts as the following:

"Japan has 436 forestry corporations or associations with a membership of 54,000 for forest management, sylviculture, forest protection and other purposes. Same country has state forests of pure stands of Sugi (Cryptomeria japonica) of such wealth as to justify the maintenance of logging railways as long as 73 miles besides 209 miles of logging track in one block of forest only. Some bamboo stands over there are cultivated chiefly for the purpose of collecting the bamboo shoots much prized as a spring vegetable. Their reforestation work covers over 250,000 acres a year with an annual planting of some $300,000,000$ plants.

Tchekoslovakia has a canal for floating purposes only "the Schwarzenbeg 
canal" 40 miles long and 6 feet wide with a tunnel 1200 feet in length built in 1790, the oldest on the continent.

Thic French Congo exports annually over 100,000,000 fect of one species alone the "okoume," possessing valuable properties for veneer work and rapidly replacing in Europe the Cedrela for the manufacture of cigar boxes.

Brazilian forests have some 2500 arborescent species out of possibly 10,000 woody plants, including shrubs and vines.

Italy has the only forest service conducted on a military system, the personnel of which constitutes "La Milizia Forestale" the forest militia.

The Netherlands with the smallest forest area of Europe, some 10 acres per 100 inhabitants maintains since 1897 a forestry school of very high standing at Wageningen, most of its graduates being employed in their colonies of the Far East. This country can hoast of being the only one having increased its forest area by $50 \%$ in the last 75 years.

Finland is the greatest exporter of plywond in the World.

India has forest products Jaboratories at Dehra Dun that compare most favorably with ours.

The sawdust of Sandalwood used for the making of joss Sticks (incense) in China is worth over $\$ 50$. a ton.

The famous angostura bitters indispensable for cocktails are prepared from the bark of the Cusparia tree grown in Venezuela.

The Vest Indies and Central America possess one of the most marvelous trees in the World for its uses, viz, the coconut palm. In passing let us mention some of them: the milk of the coconut serves as a heverage, the meat of the nut called "copra" is used for food. From it they extract oil for soap, perfume and cosmetics. After the oil is extracted the residue provides food for cattle. The shell of the coconut is made into combs, spoons etc.; the outer fibre is used to make felt, the stem of the tree goes into lumber, the tree-leaves for mats and baskets or fodder for the cattle and when the tree is felled the juice in the stump may be made into toddy or wine.

Another similar tree growing in the Tropics" the horse-radish tree" is highly esteemed. The wood is used for extracting dye, the bark contains tannic acid, some valuable gums and a fibre for making mats. The roots of young trees when scraped look like horse-radish and have exactly the same taste and use. The seeds of this tree constitute the most important product: they are called ben nuts and yield the well known and highly prized ben oil so largely used by watchmakers.

Speaking of Central America, two countries Honduras and Guatemala provide a unique product, the Chicle, the basic material in chewing gum manufacture. This chicle is a latex from the "sapodilla tree" and is col- 
lected somewhat like rubber. A ton of this necessity is worth a thousand dollars at the nearest port of the above countries.

To conclude this brief list of forestry gleanings here and there may I suggest to fellow foresters that could never bag their annual deer to take a hunting trip to New Zealand where you have the unique privilege of being paid for every stag you are lucky to bring down. In that hunter's paradise, some 12,000 deer are destroyed every year, a bounty of two shillings per head being paid by the Government, such measure being necessary to preserve the extensive state plantations which alone cover over 600,000 acres.

These enumerations are just a glimpse over the interesting field of study open to the curious-minded reader of foreign literature on forestry.

\section{EXOTIC FORESTS FROM ANNUAL REPORT OF NEW ZEALAND STATE FOREST SERVICE}

Exotic Forests. - The cessation of State exotic planting on a large scale now appears advisable. The country already possesses sufficient planted areas to supplement the indigenous forests and to ensure an adequate supply of timber, etc., for the next century. The extension of the exotic forests for the export of timber and other products cannot be justified on economic grounds. The post-war fears of a world timber famine have been definitely proved as groundless, and the following advantages enjoyed by the North European countries which dominate the international wood-goods trade cannot be lightly ignored:-

(1) The wages of both skilled and common labour being only from onequarter to one-half of those in New Zealand, manufacturing as well as forest costs are very much lower, those for forest establishment and maintenance being less than one-tenth of those in New Zealand owing to natural regeneration and absence of forest weeds and pests.

(2) Lower unit capital investments for all types of wood-converting and power plants and cheaper engineering and chemical supplies than in New Zealand result from low wages and manufacture of machinery and supplies either in their own or immediately adjacent countries. Hydro-electric power is also generated at less than half the cost in New Zealand.

(3) Not only is inland transport by river-floating, etc., the cheapest in the world, but foreign freight-rates to the world's markets, including Australia, are for all classes of wood-goods lower than from New Zealand.

The Government exotic forest activities must therefore be concentrated upon the consolidation of those areas already planted. The large-scale planting of previous years has disclosed the limitations and weaknesses of various species, 
and experimental planting of new species is fundamental to the provision of possible alternatives should any further weaknesses develop at a later stage in the establishment of the exotic forests. For similar reasons, experimental planting of exotics in cut-over forests is also contemplated.

\section{THE LOG OF THE LAB. U. S. FOREST PRODUCTS LABORATORY, MADISON, WIS. \\ Dry Kiln Methods For Seed Extraction}

Opening of the ripe seed cones of evergreen forest trees is a relatively slow natural process, often rendered more uncertain by vagaries of the weather. The most practical method of getting seed of the conifers for planting is to gather the cones at maturity and make them deliver their contents by a brief period of artificial drying.

At the request of foresters concerned with nursery and planting work, the Forest Products Laboratory recently undertook to improve the design of cone-drying equipment to secure greater speed, certainty, and uniformity of results. It was found that underlying principles of air circulation, applied so successfully by the Laboratory to the development of the internal-fan lumber kiln, were equally adaptable to cone drying - the only difference being that, with lumber, opening up or cracking of the surface must be prevented at all hazards, whereas with seed cones that is exactly the effect desired. By suitable management the kiln cycle can be made to work in either direction.

As redesigned, the new cone kiln or drying cabinet is provided with automatically regulated steam heating coils. Humidity of the atmosphere within the kiln is also subject to automatic control; if the air becomes too dry, the humidity is increased by the introduction of live steam; if too moist, it is decreased by means of outside air drawn in by a ventilating fan. Air circulation within the kiln is produced by two motor-driven fans of the straight-blade reversible-disc type. The fresh cones are placed in trays, which are stacked on a lift-truck platform and wheeled into the kiln.

Since seeds are sensitive to excessive heat, which reduces their vigor of survival and growth, it is essential that certain temperatures be not exceeded during the extraction process. The new kiln is specially designed to deliver to each tray large volumes of air at just the right temperature and humidity, so that safe, rapid, and uniform drying out of the cones is assured. The time required to open a charge of cones is less than half that required by the older equipment not provided with adequate forced circulation.

The first kiln of this type has been installed at nursery headquarters of the Ozark National Forest in Arkansas, and plans are under way for the construction of two units at a recently established Forest Service nursery in Michigan. 